\title{
AUDIT AS A FORM OF CONTROL OF THE STATE FINANCIAL INSPECTION OF UKRAINE
}

\author{
Ihor Bohdaniuk', Vladyslav Kolisnichenko², Olena Ustymenko³
}

\begin{abstract}
The aim of the article is to review the audit as a form of control of the State Financial Inspection of Ukraine and to analyse its forms and types. The subject of the study is the audit as a form of control of the State Financial Inspection of Ukraine. Research methodology. The research is based on the use of general scientific and specialscientific methods and techniques of scientific knowledge. The dialectical method made it possible to investigate the definition of the audit as a form of control of the State Financial Inspection of Ukraine and the procedure for its appointment. The comparative legal method was used in order to compare doctrinal approaches to this issue. Interpretation of the content of normative legal acts of domestic legislation was carried out with the help of the normative-dogmatic method. These acts regulate the problem of appointment and conduction of the audit. The system-structural method was used for the study of the audit institution as a whole (system) with the coordinated functioning of all its elements. Methods of analysis and synthesis helped to study some parts of this institute to formulate further conclusions about its most optimal functioning. Practical impact. The analysis of types of audits, as well as their characteristic features, helped to develop recommendations for improving the procedure for conducting audits by the State Financial Inspection of Ukraine, as well as to identify problematic issues that require further consideration and research. Correlation/originality. In the research, there was made a proposal about audits, which are carried out by the State Financial Inspection of Ukraine and its territorial bodies. The proposal was to make them a form of forecasting control. It was recommended to qualify the fact of prevention the officials of the controlling body from carrying out the audit, checking or not providing the necessary documents for audit and verification as an administrative offense. A special attention was paid to the timeliness of the selection of explanations from the involved persons during the detection of offenses.
\end{abstract}

Key words: audit, form, control, State Financial Inspection of Ukraine, financial control.

JEL Classification: M42, M48

\section{Introduction}

The form of control is an external manifestation of concrete actions, carried out by the State Financial Inspection's bodies of Ukraine, for the realization of the tasks assigned to them. Forms of control are very different, as the main function of the State Financial Inspection.

Specific forms, in which control can be made, are set with the help of different regulatory and legal acts, depending on the type of control (departmental or under departmental): from laws to internal acts, which are extending exclusively to the system of bodies of the State Financial Inspection. Taking into account all the mentioned, we can make the conclusion that the legal regulation of the forms of state financial control of the State Financial Inspection of Ukraine and its territorial bodies includes a number of problematic issues. Their solution will increase the effectiveness of control activities. Besides, we need to mention the fact that today the number of forms of financial control of the SFI of Ukraine has increased due to the allocation of the check of public procurement inspections. That is why many scientists pay attention to this mentioned form. This has led to the fact that many scientists did not pay the necessary attention to the most forms in this field. Particularly, we are talking about such a form as an audit.

\section{State of research}

Certain problematic issues of the forms of control of the SFI of Ukraine were considered only in the context of related issues. Such scientists studied these issues as: L. P. Bila, Yu. P. Bityak, G. V. Atamanchuk, A. M. Bandurka, O. M. Kurakin, A.F.Melnik, V.V.Novikov, O.P. Orliyuk, O.A.Pavlyiukh, Yu. M. Starilov, V. V. Kopeichikov and many others.

\footnotetext{
Corresponding author:

${ }^{1}$ Kharkiv Research Institute of Forensic Examinations, Ukraine.

${ }^{2}$ Kharkiv National University of Internal Affairs, Ukraine.

${ }^{3}$ Kharkiv National University of Internal Affairs, Ukraine.
} 
However, in spite of the considerable amount of scientific developments, in the legal literature, there is no comprehensive study of certain forms of control, which is carried out by the State Financial Inspection, especially we are talking about the audit.

That is why the aim of the article is: to consider the audit as a form of control of the State Financial Inspection of Ukraine.

\section{Presentation of the main material}

At the beginning of studying the main issue, we should note, first of all, that the audit is carried out to identify the facts of violation of legality, probability, and expediency. The financial and economic documentation, regarding the correctness of accounting, storage of resources and material resources, timeliness and completeness of reporting, are analysed during the audit (Voronova, 2006). In our opinion, such a description of the purpose and nature of control in this form significantly narrows the content of the phenomenon. And surely we should note that the definition of the purpose of the audit as the detection of violations of legality, probability, and feasibility is largely due to the design of item 2 of the Procedure for Conducting Inspections by the State Financial Inspection, Its Territorial Bodies, approved by the decision of the Cabinet of Ministers of Ukraine as of April 20, 2006 No. 550 (Kabinet Ministriv Ukrainy) (hereinafter - Procedure for Inspection No. 550). In this decision, it is stated that the audit "should ensure the detection of violations of the law, the establishment of guilty in their admission of officials and financially responsible persons." As we can see, the obligation to detect violations is established and this fundamentally differs from the predictive nature of control. As we have noted, this very formulation of the question directly affects the direction of control activity, bringing the punitive function of control to the forefront and the efforts of controllers to identify the facts of violations, in order to determine the control measure effective under all circumstances. As it was proved, today it is necessary to change the purpose of the control. And such changes, we consider, should find their reflection in item 2 of the Procedure for Inspection No. 550 (Kabinet Ministriv Ukrainy). It should be made in order to make audits, conducted by the State Financial Inspection of Ukraine and its territorial bodies, as a form of forecasting control. First of all, it should be aimed at developing the system, adjusting the measures, and if necessary (in case of detection of the violation) - establishing the perpetrators and bringing them to some responsibility.

There are such audits with the following features:

1. By content: they can be documentary and actual. Documentary audits can include an audit of various financial documents. During the actual audit, not only the documents are checked, but also the availability of cash and property.
2. During the period under review, audits can be frontal and selective. In the frontal (full) audit, the entire financial activity of the entity for a certain period is checked. The selective (partial) audit is a check of financial activity only for a limited period of time (Kapaieva, Liakh, 2004).

According to the criterion of control, L. K. Voronova in addition to full and partial audits also allocates complex audits, which are usually carried out by a group of specialists. They study a wide range of interdependent issues and make thematic (or targeted) revisions, which are aimed at clarifying certain issues, exploring a particular area of work (topics), a particular area of activity of the subject being examined or a particular type of operations. The scientist calls the cross-check as one of the subspecies of complex testing. It covers the financial and economic activities of several organizations or enterprises, related to each other by subordination relations (Voronova, 2006). We fully agree with the existence of these types of audits, but we consider that allocation of all four types, according to the audit criterion, is not totally correct. We consider that it is necessary to distinguish thematic and complex audits (and this is the point 3 among types of audits) according to this criterion, and frontal (full) and partial (selective) should be allocated by the criterion of the control period.

3. On an organizational basis: they can be planned (provided in the plan of work of the relevant body) (Kapaieva, Liakh, (2004); unscheduled (they are conducted to some extent, suddenly, out of plan, if there are important grounds established by the current legislation: in case of complaints from citizens or other information on violations of financial discipline, or oversight in work that requires urgent verification; or at the request of the competent state authorities) (Voronova, 2006). L. M. Kapayeva and M. S. Lyakh, according to this criterion, also distinguish complex audits, which are conducted jointly by several supervisory bodies. We believe that the selection of this type of audits should be carried out according to another criterion. Particularly, it is necessary to allocate such criteria for the distinction between different types of audits as the basis for conducting audits and subjects of financial control. Moreover, the allocation of this kind of revision is rather doubtful, because the analysis of paragraph 2.32 of the Procedure for Inspection No. 550 (Kabinet Ministriv Ukrainy) indicates the coverage of the concept of a complex audit of a certain set of financial and economic activities of the object of control. It is unlike the audit, during which only certain issues of the financial and economic activity of the object of verification are checked (and this is paragraph 3 ). Therefore, it is expedient to distinguish between audits with the involvement of specialists and joint audits, which are conducted together with the other bodies of control. They differ from the audits carried out 
exclusively by officials of the State Financial Inspection of Ukraine and its territorial bodies (this is the 5th type).

4. L.K. Voronova proposes to allocate such audits, according to the basis of the appointment as: repeated (they are conducted after a certain time after the initial financial audit, in the case when the audit process was defined as bad, or in order to control the elimination of the revealed violations. Such an inspection is carried out on the same issues and for the same period as the original one); additional (to identify issues that were not addressed before the initial inspection, and mainly due to new circumstances) (Voronova, 2006).

We believe that the criterion for differentiation of these kinds of revisions is rather exact because, on the basis of the distinction, we can distinguish scheduled and unscheduled audits. The same types of data are allocated based on the necessity of assigning another, except for the primary audit, due to quality or new circumstances.

5. Based on destination, L. K. Voronova proposes to highlight such audits as a repeat (it is conducted after a certain time after the initial financial audit if it is recognized as poorly conducted, or in order to control the elimination of the revealed violations).

6. By place of conduct: audits can be field (carried out at the location of the object of control) and cameral (conducted at the location of the financial control body).

7. By the nature of the monitored indicators: the formal ones, which verify the correctness of the documents (for example, when it is necessary to determine the validity of signatures, the presence of corrections, the correctness of filling the requisites); arithmetic (they evaluate the correctness of mathematical calculations and taxonomy) (Voronova, 2006). Regarding the procedure for audits and the implementation of their results, as in the case of public procurement audits, planned audits are conducted on the basis of the audit program, which consists of two copies, with the handing of one of them to the object of control under the receipt (Clause 4-7 of the Procedure for Inspection No. 550 (Kabinet Ministriv Ukrainy)). Unplanned audits have well-defined bases for conduction, without which audit out of the plan is not allowed. Particularly, such bases are introduced in Art. 11 of the Law of Ukraine "On the Basic Principles of Implementation of the State Financial Control in Ukraine" as of 29 January 1993 No. 2939-XII (Verkhovna Rada Ukrainy). Unplanned field audits of subjects of economic activity, regardless of ownership, which are not assigned to the controlled institutions by the mentioned Law, are carried out by the state financial control bodies by a court decision, adopted on the basis of a petition of the investigator, the prosecutor to ensure the investigation during the criminal proceedings. A publicfinancial controlbody, prosecutor or investigator initiating an unscheduled outbound audit, submits to the court a written substantiation of the grounds for such an audit and the date of its commencement and termination, and documents, which according to parts five and seven of this article proves about the origin of the bases for such an audit, and for the request of the court - they give other information (Poriadok provedennia perevirok orhanamy derzhavnoi finansovoi inspektsii Ukrainy).

One of the distinctive features of a planned and unscheduled audit is the announcement of their beginning of the control object. If during the conduct of a planned field audit, the subject of control reports to the control object one of the specified methods on the dates of its beginning and ending (at the same time, the planned field audit starts no earlier than 10 calendar days after the message control object is sent). But unscheduled audits are conducted without any notice (paragraph 8 of the Inspection Procedure No. 550).

In order to begin the field audit, officials of the controlling body and the involved specialists should be admitted to the objective. In the presence of the bases provided in the law, it is necessary for admission to show the direction and the copy of the judgment, which should be presented on a receipt (in case of unscheduled field audit by a court decision) (Clause 12 of the Procedure for Inspection No. 550 (Kabinet Ministriv Ukrainy)). The direction for the audit should include the date of its issue, the name of the state financial control body, purpose, type, grounds, the date of the beginning of the audit and the date of its completion, the position, title and surname of the officials of the state financial control body that will conduct the audit. The audit direction is valid on the condition of the existence of the signature of the head of the state financial control authority, which is sealed by the state financial control body. A court decision on permission for carrying an unscheduled field audit, which copy is submitted to the object of control, it should include the bases for such an audit, the date of its beginning, and the date of termination. And in case of carrying out an audit of subjects of economic activity that are not covered by the Law of Ukraine "On the Basic Principles of Implementation of the State Financial Control in Ukraine” dated January 26, 1993, No. 2939-XII, to the controlled entities, there also should be a number of criminal proceedings, body conducting the pre-trial investigation, date and grounds for notification of suspicion of a criminal offense (Poriadok provedennia perevirok orhanamy derzhavnoi finansovoi inspektsii Ukrainy).

It this context, it is necessary to pay attention to the problem of legal regulation of counteraction to officials of the State Financial Inspection of Ukraine and its territorial bodies, and to specialists, who are involved in the audit, or their absence of access to the objects. The matter is that the structure of such offense as "impeding employees of the state financial control body in carrying out audits and inspections" is provided in Art. 164-2 The purchase of the AP, entitled "Violation of the legislation on financial matters" and it includes, in addition to the specified composition, five more. 
From their number, four relate to the object of control of the event (accounting reports, accounting, etc.), one relates to the conduction of it (interference), and the last relates to the period after the control measure (rejection of measures to compensate the perpetrators for losses from shortages, wastes, theft and mismanagement). As we can see, the composition of offenses is composed in one article, but it should be resolved in some separate articles while specifying the objective side of such an offense as an obstacle. Particularly, it seems necessary to clearly state that the prevention of officials of the controlling body to carry out audits, inspections or non-provision of necessary for audit, and checking documents is among the number of actions that should be classified as an administrative offense: for today it is "Violation of legislation on financial issues", in the future, we consider it will be a separate article. If we talk about the audit, then the place and access to information, documents of the controllers should be provided to the objects. The audit in accordance with paragraph 16 of the Procedure for Inspection No. 550 (Kabinet Ministriv Ukrainy), as well as the examination of public procurement, is carried out by two complicated content methods: actual or documentary verification. An actual check can include an inventory, inspections, and control measurement of the performed works, the correctness of use of raw materials and materials consumption norms, the output of finished goods and natural losses by organizing control starts into production, control analyses of finished goods and others of similar actions with participation of the corresponding specialists of supervisory authority or other bodies, enterprises, institutions and organizations.

In accordance with clause 18 of the Procedure for Inspection No. 550 (Kabinet Ministriv Ukrainy), in case of detection of violations of the legislation, officials of the controlling body should require written explanations from the employees of the control object, who are involved in the revealed violations. Officials of the controlling body may require written explanations from the employees of the object of control in order to clarify the individual circumstances of the financial and economic activity of the object of control. Besides, they can also require information from other persons in accordance with the Law. We want to pay attention to the principled discrepancy of the control subjects in case of detection of violations of persons involved in violations, and other employees of the object of control. The audited officials are required to take an explanation from them when it comes to the involved persons. And this is logical in view of their further use in the case file of the violation. The timeliness of the selection of explanations will contribute to their objectivity. The lack of time for discussion and understanding and judgment of the revealed violation allows obtaining accurate information. And on the contrary, when the discussion took place, and the person had some time to think, then explanations can differ radically from those, which were received by auditor's right after identification of the fact. Therefore, the obligations to collect explanations from all persons are quite logically available in a complex of powers of the body of financial control.

In contrast to this obligation, the right of the controller to collect additional information about the fact of the commission of the offense also exists. They can do it due to the selection of explanations from the employees of the control object or other persons not involved in the commission of the offense. Such explanations are extremely important regardless of the subject, who will consider and make decisions on drawing up the protocol, the opening of criminal proceedings, and further consideration of the case.

Separately we should mention the right to initiate the issue of extracting originals of financial and economic and accounting documents, which testify about the violation of the law. Besides, the object of control is not guaranteed their preservation and the possibility of their forgery is not excluded also (paragraph 20 of the Procedure for Inspection No. 550 (Kabinet Ministriv Ukrainy)). Such rights, as well as the obligation to take explanations, in the future, can ensure the possibility of proving certain persons in committing an offense (either criminal, or administrative, or any other) in the manner prescribed by law.

\section{Conclusions}

Thus, the State Financial Inspection of Ukraine during making the control in the form of an audit, its results and conclusions are included in such act as a document, which officially formalizes the course of the control measure, its results and conclusions made by the subject of control. In this context, it should be noted that in practice there are some unusual facts when, during establishing violations or their features, the auditors do not carry out a proper set of audit activities. And, as a result, such facts are not qualified as a violation, and its amount is not calculated and accordingly, it is not presented to the guilty parties. And therefore, the violation can be mentioned in the act (certificate), but however, the responsible person is not identified and nobody deals with the return of the lost sums of money. There is also a practice of not well quality documentation of violations, ranging from elemental lack of references to violated legal acts and grammatical mistakes ending with illegal and unconfirmed conclusions. Sometimes, these mistakes make it impossible even to understand the essence of the statement outlined in the act. That is why, there is no doubt that only the competent, consistent, complete statement of information, which was received by the auditors during the control measure, contributes to the achievement of the objective of financial control. Therefore, managers have to pay attention to these issues constantly. 
Vol. 4, No. 5, 2018

\section{References:}

Voronova, L. K. (2006). Finansove pravo Ukrainy: Pidruchnyk [Financial Law of Ukraine: studybook]. Pretsedent; Moia knyha.

Kabinet Ministriv Ukrainy. Postanova Pro zatverdzhennia poriadku provedennia inspektuvannia Derzhavnoiu finansovoiu inspektsiieiu, yii terytorialnymy orhanamy vid 20.04.2006 № 550 [Cabinet of Ministers of Ukraine. Resolution on Approval of the Procedure for Inspection by the State Financial Inspectorate, its territorial bodies dated April 20, 2006 No. 550]. Retrieved from: http://zakon3.rada.gov.ua/laws/show/550-2006-\%D0\%BF/ card2\#Card

Kapaieva, L. M., Liakh, M. S. (2004). Finansove pravo: Navchalnyi posibnyk [Financial Law of Ukraine: studybook]. Kyiv: Tsentr navchalnoi literatury.

Verkhovna Rada Ukrainy. Zakon Ukrainy «Pro osnovni zasady zdiisnennia derzhavnoho finansovoho kontroliu v Ukraini» vid 26.01.1993 № 2939-XII [Verkhovna Rada of Ukraine. The Law of Ukraine "On the Basic Principles of the Implementation of the State Financial Control in Ukraine" of 29 January 1993 No. 2939-XII]. Retrieved from: http:/ zakon3.rada.gov.ua/laws/show/2939-12

Poriadok provedennia perevirok orhanamy derzhavnoi finansovoi inspektsii Ukrainy [The procedure for conducting inspections by the bodies of the State Financial Inspection of Ukraine]. Retrieved from: http://www.tvoiprava.com.ua 